\title{
Developing the Sociocultural-Based Thematic-Integrative Learning Module for Improving the Learning Motivation and the Critical Thinking
}

\author{
Sulistiya Ingwarni \\ SD Terban, Cangkring. Sidomulyo, Bambanglipuro, Bantul, Indonesia \\ *Corresponding Author. Email: listya_ys@yahoo.co.id \\ Received: 10 August 2017; Revised: 2 January 2018; Accepted: 9 January 2018
}

\begin{abstract}
The study aims at: (1) generating a sociocultural-based thematic-integrative learning module that will be feasible for improving the students' learning motivation and critical thinking skills; and (2) identifying the effectiveness of the sociocultural-based thematic-integrative learning module for improving the students' learning motivation and critical thinking. The study is research and development (R\&D) effort. Thus, the procedures within the study adapt the development procedures that have been proposed by Borg \& Gall as follows: (1) preliminary study; (2) planning; (3) product design; (4) preliminary field testing; (5) revision based on the results of the preliminary field testing; (6) main field testing; (7) revision based on the results of the main field testing; (8) operational field testing; and (9) final product revision. Then, the subjects in the study are the students from Grade IV Jejeran Elementary School Bantul. The results of the study show that: (1) the sociocultural-based thematic-integrative learning module is already feasible according to the assessmsne tof the media expert and the material expert with "Very Good" category; and (2) the sociocultural-based thematic-integrative learning module is effective for improving the students' learning motivation and critical thinking skills. The conclusion is based on the fact that the score of the operational field testing shows $p<0.05$, which implies that there is significant difference in terms of learning motivation and critical thinking skills between the students who use the learning module and the students who do not use the learning module.
\end{abstract}

Keywords: module, thematic-integrative, sociocultural-based learning, learning motivation, critical thinking

How to Cite: Ingwarni, S. (2018). Developing the socioculture-based thematic-integrative learning module for improving the learning motivation and the critical thinking. Jurnal Prima Edukasia, 6(2), 157-165. doi:https://doi.org/10.21831/jpe.v6i2.9447

Permalink/DOI: https://doi.org/10.21831/jpe.v6i2.9447

\section{Introduction}

Curriculum is one of the elements that hold important role in achieving good quality within education. As having been stated in Law Number 20 Year 2003 Regarding National Education System in Chapter 1 Article 1, curriculum refers to a set of plans and regulations on the teaching contents, materials, and methods that should be implemented as the guidelines for the conduct of learning activities in order to achieve the objectives of certain educational efforts. Therefore, changes on curriculum is reasonable in terms of adjustment toward the expansion of educational quality.

The development of 2013 Curriculum as a follow-up from the development of Educational Unit Level Curriculum (KTSP, Kurikulum Tingkat Satuan Pendidikan) is intended to generate the reliable and well-qualified graduates for tackling the ever-developing global challenges. As a result, numerous efforts have been performed by the government in order to improve the educational quality and one of these efforts is developing a curriculum that might improve the students' critical thinking skills. The scientific approach as one of the fundamental aspects within the learning process of 2013 Curriculum is one of the matters that reflect the efforts of developing the learning process within the curriculum.

Critical thinking is a mental process that generates the capacity of discerning numerous alternatives of solution in the problem-solving activities. Santrock (2007, p.271) states that critical thinking involves grasping the deeper meaning of ideas, keeping an open mind about 
different approaches and perspectives, and deciding for oneself what to believe or do.

The development of the learning process that might improve the students' critical thinking skills is necessary as an effort of improving the students' critical thinking skills for preparing the students to tackle the changes that occur in the future. Massa (2014, p.387) states that learning process that has been based only on the materials within the curriculum will not improve the students' critical thinking skills such as reasoning, flexible and creative thinking, problem solving, and decision making. Therefore, it is very important to habituate the students to develop or improve their critical thinking skills as early as possible. According to Jane (1994, p.109), children use their critical thinking skills since they are young or they are entering the pre-school age. When the critical thinking skills are developed within the period of early school age, the children will respond to the development of their critical thinking skills by being a more effective critical thinker. Within the further period of their education, the students will be more consistent thinker and thus their critical thinking skills will be more meaningful in their future life.

The students' success within the process of improving their critical thinking skills cannot be set apart from their own learning motivation. Similar to the opinion by Schunk, Pintrich \& Meece $(2015$, p.5) state that learning motivation might influence what an individual is learning, when an individual is learning, and how an individual is learning. The students who are motivated to learn about certain topics tend to engage themselves in numerous activities that will assist their learning such as looking at all instructions carefully, arranging and exercising on the materials that they have been learning, composing notes for the next learning materials, checking the level of their understanding, and seeking for assistance when they do not understand certain learning materials. On the other hand, the students who are not motivated to learn will not be systematic. These students will not pay attention to the learning materials, will not arrange and exercise on their learning materials, will not regularly compose notes for the next learning materials, will not monitor the level of their understanding, and will not seek for assistance whenever they do not understand certain learning materials. The bottom line is that learning motivation results in a reciprocal relationship between learning process and learning performance; in other words, learning motivation will influence learning process and learning performance. Thus, learning motivation has highly significant influence on the students' academic performance (Tella, 2007, p.149).

According to 2013 Curriculum, the learning process should be conducted in an thematicintegrative manner; this kind of manner combines several learning topics into certain learning themes based on the aspect of children's development and knowledge attainment. The theme selection and the learning concept presentation from the contextual source intend to deliver a complete and meaningful learning process. Liu \& Wang $(2010$, p.26) state that thematic learning has positive impacts on the development of the students' concepts and is very necessary to be applied to the students who have different capacities. In this case, the concept of thematicintegrative learning process is not different from the concept of sociocultural-based learning process.

The sociocultural-based learning process departs from the reality that education cannot be set apart from the aspects of family background and community life. The reason is that learning is not a process that occurs not only within an individual but also within two individuals or more. The statement implies that social interaction has important role within the process of knowledge construction (Kozulin, Gindis, Ageyev, \& Miller, 2007, p.17). Education takes place in the life of civilized community. Human personality is shaped from the cultural values that exist in the surrounding environment. Therefore, educational process can be seen as a process of civilization and learning process can be seen as a process of appreciation toward culture (Tilaar, 2004, p.190).

Paying attention to the Appendix of the Minister of Education and Culture Regulation Number 67 Year 2013 Regarding the Basic Framework and Structure of Elementary School/ Madrasah Ibtidaiyah Curriculum, it is mentioned that the philosophical foundation within the development of 2013 Curriculum originates from the objective of developing the present and future life of the nation, which has been developed from the inheritance of cultural values and nation achievement in the past for the future life (Kementerian Pendidikan Nasional, 2013). The statement implies that curriculum always put the learning participants in their sociocultural environment, develop the students' individual life as a citizen without losing the personality and 
quality for the better life in the present time, and build the better life in the future. Thus, from the statement it might be concluded that one of the curriculum development efforts within the education cannot be set apart from the aspects of socio-culture.

Within the implementation of 2013 Curriculum, the government has provided teacher guidebook and student guidebook as the guidelines of learning process conduct. The teacher guidebook and the student guidebook contain the guidelines on the learning materials and procedures that should be performed every day. If the guidelines are carefully examined, then the material presentation in the student guidebook is still limited. The teachers are expected to develop the learning materials in accordance to the potentials, the conditions, and the characteristics of each school in order that the learning objectives might be achieved well. The implication is that the teachers should be able to develop other learning materials as a complimentary to both the teacher guidebook and the student guidebook.

In order to describe the case, a needs analysis was conducted in Jejeran Elementary School from July $27^{\text {th }}$ until July $28^{\text {th }} 2018$ through interview, learning observation, and library study. The results of the interview show that the teachers have implemented 2013 Curriculum in the learning process. In the implementation of 2013 Curriculum, the teachers have found several obstacles in the form of learning time allocation insufficiency and learning materials limitation in the student guidebook that has been published by the government. The obstacles in the form of learning time allocation insufficiency cause the teachers to add learning periods or to hold private courses so that the students might master the learning materials well. In addition, the teachers should also be creative in developing respective learning materials in the school. The teachers only rely on the student worksheets from the private publishers as the additional learning materials. The use of student worksheets seems to be unable to solve the problems related to the learning time allocation. Not to mention, the reason is that the use of student worksheets still needs the teachers' guidance. In other words, the teachers need learning materials that the students might learn independently so that they can master the materials well without having to attend additional learning period/private courses in the school.

In relation to the sociocultural aspect, the teachers of Grade IV in Jejeran Elementary
School actually have understood that there are many sociocultural aspects that might be turned into the parts of maximum learning materials development. However, these teachers have not been able to pursue such maximum learning materials development. They only afford to insert the additional materials orally and spontaneously within the learning process. Thus, the sociocultural-based learning process have not been planned and document well. These findings are not different from those from the observation on the learning process, which show that the conduct of the learning process have not involved the sociocultural aspects. As a result, the learning motivation of Grade IV students is still low. Such low motivation is shown by several aspects namely task completion, persistence level, and achievement desire that have been low. In the same time, the students' critical thinking skills are still low since most of the students are unable to formulate questions, to provide answers with reason, and to draw conclusions.

The results of the observation on the use of learning materials show that the teachers are still focused on the use of student guidebook that has been published by the government. The additional learning materials that have been used are only the student worksheets from the private publishers. The teachers have not developed their own learning materials in accordance to the needs of their school. In addition, the learning modules have been unavailable as well in the school.

Based on the situation, the teachers seem to demand the development of integrative thematic learning materials that the students might use independently. The use of sociocultural aspects as the source of material development for the students can be the solution for the problems in the Jejeran Elementary School. As a result, the development of sociocultural-based thematicintegrative learning module can be a learning materials development that might be expected to improve the students' learning motivation and critical thinking skills.

The sociocultural-based integrative thematic learning module in the form of thematicintegrative learning package that has been designed systematically can be used by the students independently and the materials in the learning package can be integrated into the sociocultural aspects within the region of the Province of Yogyakarta Special Region. In addition, the learning module in the learning package is presented with interesting pictures and colours, the use of simple sentences, and the 
learning activities that involve the students' interaction with the sociocultural aspects; therefore, it is expected that the learning module might improve the students' learning motivation. According to the results of a study by Chao, Lin, \& Wang (2015, p.405), the design of their learning module is able to improve the students' learning motiva-tion. Through the use of the module, the students' have better concept understanding and process skills. The results of a study Goodson-Espy, et.al., (2014, p.392) in addition shows that the students' concept understanding and self-efficacy have been improved after they use the design of her learning module.

Furthermore, a study by Roberts \& Dyer (2005, p.12) show that the students who have high learning motivation will display high learning achievement and better behavioural changes. As a result, within the learning module that has been developed the learning activities that have been designed to improve the students' critical thinking skills are presented. These learning activities are presented with analytical questions and in-depth thinking so that the students' skills in formulating questions, defining the reason behind an answer, drawing conclusions can be exercised as part of their critical thinking skills. According to the argument by Peter (2012, p.39), critical thinking skills serve like the other skills that demand exercise, practice, and habituation. One of the most important matters that should be done is encouraging the students in the process and the model of habituation in-depth thinking behaviour so that their critical thinking skills might be improved. In this case, the students' critical thinking skills might be developed through the habituation of critical questions that the teachers provide and the regular engagement of the students into the learning process actively.

From the overall background, it can be concluded that the teachers demand the learning materials that the students might use independently. These learning materials will serve as the complimentary of both the teacher guidebook and the student guidebook. The statement is in accordance to the results of a study by Purnomo \& Wilujeng (2016, p.67), who have found that the development of learning materials as the complimentary to the teacher guidebook and the student guidebook is effective for improving the students' knowledge, attitudes, and skills. Another study that might be relevant is the one by Barus \& Djukri (2013, p.222), who have found that the development of thematic textbooks for the students is effectives for improving the students' learning results. The development of necessary learning materials should be in the form of sociocultural-based thematic-integrative learning module so that the problems on the lack of learning materials development might be solved. Thus, the learning module is intended as learning materials that provide learning materials based on the students' sociocultural aspects for improving the students' learning motivation and critical thinking skills. In other words, the learning module serves as the complimentary book for the teacher guidebook and the student guidebook.

\section{Method}

The study relied on the research and development model that had been proposed by Gall, Gall, \& Borg (2003, p.775). Specifically, the research and development efforts had been proceeded until the ninth procedure; thus, the complete procedures in the study were as follows; (1) preliminary study; (2) planning; (3) product design; (4) preliminary field testing; (5) revision based on the results of preliminary field testing; (6) main field testing; (7) revision based on the results of main field testing; (8) operational field testing; and (9) final product revision.

The procedure of product testing consisted of three stages namely preliminary field testing, operational field testing, and main field testing. Prior to the testing, the learning module was validated first by the material experts and the media experts. Then, the subjects in the study were the students from the Grade IV of Jejeran Elementary School in Bantul. Three students were selected from Grade IV B and nine students were selected from Grade IV A in the preliminary field testing. In overall, 30 students from Grade IV A served as the experimental group while 30 students from Grade IV $\mathrm{C}$ served as the control group. Next, the data gathering instruments that had been employed in the study were product assessment scale, learning motivation scale, teacher and student response scale, and critical thinking test.

The data that had been gathered before the conduct of the study in the form of interview, observation, and library study results served as part of the needs analysis for the learning module development. These data were analysed using the qualitative data analysis technique based on the argument by Miles \& Hubberman (2014, p.12) and the data analysis technique consisted of three 
stages namely data condensation, data display, and conclusion drawing/verification. Then, the data that had been gathered after the conduct of the study became the quantitative data; the quantitative data were analysed in order to generate feasible and effective learning module. The feasibility of the product that had been generated was analysed by means of five-scale score conversion. The assessment were considered to meet the criteria if the minimum category that had been achieved were "Good."

\section{Results and Discussions}

Preliminary Study

Based on the results of the interview, it might be concluded that the teachers have implemented 2013 Curriculum and consequently the learning process has been conducted according to the thematic-integrative manner. However, there is an obstacle within the conduct of the thematic-integrative learning process. The obstacle is found in the adjustment between the allocation of learning period and the number of materials that the students should master. The main learning materials that the students should master is the student guidebook. The materials in the student guidebook are still limited and have less in-depth discussion; as a result, the students still demand other learning materials as complimentary to the main ones. Not to mention, the teachers themselves demand the learning materials that the students might use independently. The intention is that the students will be able to learning independently both in the school and in the house; the independent learning can be a solution for assisting the students in understanding their learning materials. In relation to the sociocultural-based learning process, it can be concluded that the teachers have understood the learning materials but they have not been able to apply the learning materials well.

The results of the observation show that the teachers have implemented the integrative thematic approach within the learning process. The learning methods and media that the teachers have implemented are already variative yet they have not integrated the sociocultural aspects into the learning process. In relation to the student guidebook, the teachers rely on the student worksheets that have been published by the private publishers and the Educational Unit Level Curriculum books as the supporting learning materials. All of the learning materials that the teachers have used are still general and have not specifically integrated the sociocultural aspects. Therefore, in general it might be concluded that the students' learning motivation is still low. Based on the results of the observation, many students have not completed their tasks, many students have only completed the tasks that they consider easy, many students have not tried to complete the difficult tasks, and many students have not tried to get the best score. Not to mention, the students' critical thinking skills also display low learning achievement. This situation is described by the fact that many students have not been able to formulate their questions well, many students have answered questions without logical reasons, and many students have not been able to draw conclusions well.

Then, in the stage of library study a literature analysis was conducted toward the learning materials. The results of the library study have been put into the theoretical review. Next, the operational definitions that have been attained are put into the guideline draft and the instrument for designing the learning materials product that is suitable for the needs of Jejeran Elementary School in the form of a learning module.

From the results of the preliminary study, it might be concluded that the teachers demand thematic-integrative learning materials that the students might use independently. Based on the conclusion, throughout the study a learning module with adjustment to 2013 Curriculum will be developed. The development of the learning module will be integrated with the sociocultural aspects in the Province of Yogyakarta Special Region. It is expected that the development of such learning module might increase the students' learning motivation and critical thinking skills among the Grade IV students in Jejeran Elementary School.

\section{Data from the Expert Validation Results}

The data from the product assessment by the material experts based on the five-scale score conversion in sub-variables of content compatibility, linguistic compatibility, and component completeness within the module show that the learning module belongs to the "Good" category. In addition, the assessment by the media expert in the sub-variables of presentation and graphic show that the learning module belongs to the "Very Good" category. Such assessment implies that the learning module is already feasible for implementation after revision. 
Analysis on the Data from the Preliminary Field Testing

\section{Learning Scale Motivation}

The assessment on the students' learning motivation is based on the preliminary measurement of learning motivation, namely on the students' learning motivation before the use of the module and the students' learning motivation after the use of the module. The results from the scale of preliminary learning motivation show that the mean score is 38.00 with "Moderately Good" category while the results form the scale of final learning motivation show that the mean score is 44.00 with "Good" category.

\section{Critical Thinking Skills Test}

The assessment on the students' critical thinking skills is based on the pre-test and the post-test results. The pre-test results (before the use of the module) show that the mean score is 4.00 with "Poor" category while the post-test results (after the use of the module) show that the mean score is 8.00 with "Good" category.

Analysis on the Data from the Main Field Testing

\section{Learning Motivation Scale}

The following is the diagram that describes the improvement on the students' learning motivation in the main field testing.

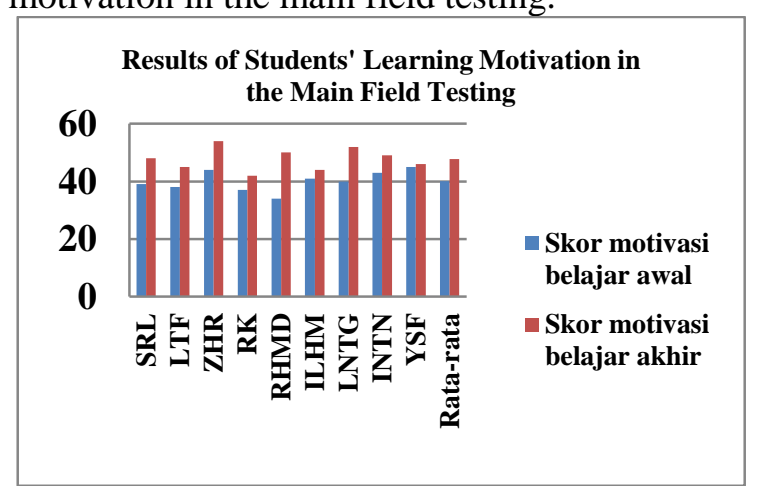

Figure 1. Graphic of Comparison on the Students' Learning Motivatin in the Main Field Testing

The Figure 1 shows the improvement on the learning motivation from 9 students as the subjects in the main field testing. The score of the students' learning motivation after using the module is higher in comparison to the score of the students' learning motivation before using the module.

\section{Critical Thinking Test}

The following is the diagram that describes the improvement on the students' critical thinking skills in the main field testing.

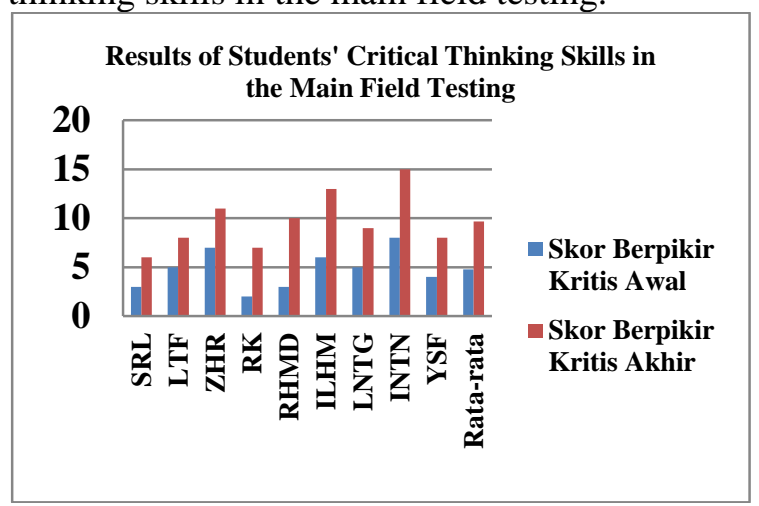

Figure 2. Graphic of the Comparison on the Students' Critical Thinking Skills in the Main Field Testing

The Figure 2 shows the improvement on the students' critical thinking skills in the main field testing. The final score of the students' critical thinking skills is higher after the use of the sociocultural-based thematic-integrative learning module in comparison to the preliminary score (before the use of the learning module).

Analysis on the Data from the Effectiveness Test in the Operational Field Testing

\section{Learning Motivation}

The results of the paired t-test in the experimental group show that $\mathrm{p}<0.05$; therefore, it might be implied that there is significant improvement on the learning motivation of the students' who use the learning module. On the other hand, the results of the independent $t$-test show that $\mathrm{p}<0.05$; thus, it might be implied that the students' learning motivation in the final measurement shows significant difference between the control group and the experimental group.

\section{Critical Thinking Skills}

The results of the paired t-test in the experimental group show that $\mathrm{p}<0.05$; therefore, it might be implied that there is significant improvement on the critical thinking skills of the students who use the learning module. On the other hand, the results of the independent t-test show that $p<0.05$; thus, it might be implied that the students' critical thinking skills in the post test show significant difference between the control group and the experimental group. 
Jurnal Prima Edukasia, 6 (2), July 2018 -163

Sulistiya Ingwarni

\section{Teachers' and Students' Response}

The teachers' response on the sociocultural-based thematic-integrative learning module is very good. Similarly, the students' response on the learning module is also very good.

\section{Discussions}

The learning module that has been developed in the study is feasible for implementation in the thematic-integrative learning process with the subtheme "The Beauty of Historical Inheritance" for the Grade IV students according to the material experts and the media experts. Furthermore, based on the assessment by the experts, the learning module has already had the correct concept, has already been presented with clear directions and has already had materials that are compatible with the core competences and the basic competences in terms of sociocultural aspects in the Province of Yogyakarta Special Region. Then, the components in the learning module have already been in accordance to the characteristics of a module design as having been stated by the Department of National Education (2008) namely self-instructional, self-contained, stand-alone, adaptive, and user-friendly. The self-instructional characteristic intends to habituate the students to learn independently through the use of the module (Departemen Pendidikan Nasioanl, 2008, pp. 3-5). The habituation of independent learning process is displayed by the presence of the following components: direction, objective formulation, contextual learning materials, exercise and task items, material summary, evaluative test items and also feedback upon assessment. The learning materials in the overall basic competences are designed completely in the module so that the characteristic of self-contained might be met. Next, the use of the module does not depend on the other media so that the characteristic of stand-alone might be met. The module is also up to date in terms of science and technology development and the module might be used within certain period of time as long as the curriculum is still relevant so that the characteristic of adaptive might be met. Last but not the least, the characteristic of user-friendly can be found in the use of simple and communicative language according to the module users namely the Grade IV students of Jejeran Elementary School Bantul.

The learning module is presented by using the brief and simple language that suits the characteristics of the module users namely the elementary school students. In addition, the texts of the learning materials are accompanied by figures as the illustration so that the students will have better understanding toward the materials that are delivered and thus the students will be more motivated in the learning process through the use of the learning module. In this regard, the module has relied on the design techniques so that the module will be interesting, informative, and suitable for the students' characteristics. According to Arsyad (2011, pp.87-91), the aspects of designing the printed learning materials are as follows: consistence, format, organization, attractiveness, font size, and blank space. In addition, attention should be given to the compatibility between the module design and the principles of simplicity, cohesiveness, emphasis, balance, form, line, colour, and texture.

The learning module displays analytical questions that demand in-depth thinking. These questions can serve as a tool for exercising and improving the students' critical thinking skills. The statement is in accordance to the argument by Thompson $(2011$, p.4) who mentions that effective questions are one of the best strategies that teachers might benefit in developing the students' critical thinking skills. Snyder \& Snyder (2008, p.95) state that critical thinking skills are the skills that might be mastered yet these skills demand instruction and practice. The learning activities that involve the students in a project, in the use of effective questioning techniques, and in the use of critical thinking skills guideline/instruction can be one of the ways for promoting the critical thinking skills. Then, the teachers' challenge is turning the students into the information users rather than the information receivers. The design of learning activities in the learning module demands the students' active involvement in attaining their own information. The students are given with certain tasks that urge them to observe the sociocultural aspects around them and to compare these sociocultural aspects to the ones in the past with the help from their parents. For example, the students are asked to attend a funeral in their village. Then, they have to pay attention to the tombstone. Based on the observation, the students have to analyse the change of the tombstone from the Stone Age, like the one that has been found in Sokoliman Site, to the present time. This kind of learning activities will encourage the students' curiosity toward the sociocultural changes in their community. As a result, the students will be trained to perform their critical thinking skills more than before. 
Based on the results of the field testing, the sociocultural-based thematic-integrative learning is able to improve the students' learning motivation and critical thinking skills. The improvement on the learning motivation can be seen from the comparison between the preliminary score and the final score, while the improvement on the critical thinking skills can be seen from the comparison between the pre-test score and the posttest score. Then, based on the t-test results statistically it is apparent that there are differences on both the students' learning motivation and the students' critical thinking skills between the experimental group and the control group. The experimental group has higher improvement than the control group.

The students who use the socioculturalbased thematic-integrative learning module can be independent learners. The learning module is able to provide student-centred learning environment, more simplified coverage on knowledge and further exploration that enables the interaction between the teachers and the students (Dai $\&$ Turgeon, 2008, p.68). The use of the learning module is related to the students' academic achievement. The achievement is influenced by the fact the students have better understanding toward the materials. Cenghizen (2008, p.98) states that the modular learning design has higher impact toward the success in the students' longterm retention level. The learning module is able to improve the students' understanding (Jin \& Bennur, 2012, p.31). The learning module is designed to encourage the students' activeness rather than the students' ability to receive information since the learning module is able to improve the students' learning responsibility. The learning module is able to encourage the students to improve as quick as they can and to spend their extra time on understanding the most difficult part (Bergen Jr, \& Han-fu, 2002, p.29).

\section{Conclusions}

The sociocultural-based integrative thematic learning module that has been developed in the study is feasible for implementation in the integrative thematic learning process according to the assessment by both the material experts and the media experts. The category of the learning module itself is "Very Good."

The sociocultural-based integrative thematic learning module is proven to be effective for improving the learning motivation and critical thinking skills in the Grade IV students of Jejeran Elementary School. The effectiveness is based on the t-test results, which shows $\mathrm{p}<0.05$. The implication of the t-test results is that there is significant difference on the students' learning motivation and critical thinking skills between the experimental group (the students who use the learning module) and the control group (the students who use the government-issued learning materials).

The development of the socioculturalbased integrative thematic learning module has been tested in terms of feasibility and effectiveness. Based on the testing, it is suggested that the teachers should: (1) use the learning module as an alternative in preparing the thematic-integrative learning process within the Grade IV specifically for improving the students' learning motivation and critical thinking skills; and (2) develop the learning materials in the form of learning module for the other themes or subthemes by adjusting the learning materials to the students' characteristics or the surrounding environment.

\section{References}

Arsyad, A. (2011). Media pembelajaran. Jakarta: Raja Grafindo Persada.

Barus, Y., \& Djukri, D. (2013). Pengembangan buku teks tematik tema permainan untuk kelas III SDN Tridadi Sleman Yogyakarta. Jurnal Prima Edukasia, 1(2), 222-234. doi:http://dx.doi.org/10.21831/jpe.v1i2.26 $\underline{38}$

Bergen Jr, T. J., \& Han-fu, M. (2002). Peer tutoring and the self-instructional module. Educational Research Quarterly, 25(4), 28.

Cengizhan, S. (2008). Determining the effect of modular instruction design on the academic achievement and long-term retention of students with different learning styles. Journal of theory and practice in education, 4, 98-116. Retrieved from: http://eku.comu.edu.tr/index/4/I/ sum_scengizhan.pdf.

Chao, L. L., Lin, C. C., \& Wang, W. L. (2015). Teaching and promotion on inquirybased instructional module. European Scientific Journal, ESJ, 11(10), 25-39

Dai, J., \& Turgeon, A. J. (2008). Loop-imbedded (non-linear) instruction modules: A novel delivery method for online learning. Journal of Natural Resources \& Life Sciences Education, 37(1), 63-68. 
Departemen Pendidikan Nasional. (2008). Penulisan modul. Jakarta: Depdiknas.

Gall, M.D \& Gall, J.P., \& Borg, W.R. (2003). Educational research: an introduction $\left(7^{\text {th }}\right.$ ed.). Boston: Pearson Education, Inc.

Goodson-Espy, T., Cifarelli, V. V., Pugalee, D., Lynch-Davis, K., Morge, S., \& Salinas, T. (2014). Applying NAEP to improve mathematics content and methods courses for preservice elementary and middle school teachers. School Science and Mathematics, 114(8), 392-404.

Jane, D.S. (1994). Critical thinking in young children. Doctoral Disertation, The University of North Carolina, 1994). UMI.

Jin, B. \& Bennur, S. (2012). Curriculum internationalization focusing on india: preand post-assessment of student learning. Journal of Teaching in Implementational Business, 23, 31-45.

Kementerian Pendidikan Nasional. (2013). Peraturan Menteri Pendidikan \& Kebudayaan nomor 67, tahun 2013, tentang kerangka dasar dan struktur kurikulum sekolah dasar/madrasah ibtidaiyah.

Kozulin, A., Gindis, B., Ageyev, V. S., \& Miller, S. M. (Eds.). (2007). Vygotsky's educational theory in cultural context. Cambridge University Press.

Liu, M.C. \& Wang, J.Y. (2010). Investigating knowledge integration in web-based thematic learning using concept mapping assessment. Educational Technology \& Society, 13, 25-39.

Massa, S. (2014). The development of critical thinking in primary school: the role of teachers' beliefs. Procedia-Social and Behavioral Sciences, 141, 387-392. https://doi.org/10.1016/j.sbspro.2014.05.0 68

Miles, M.B., Huberman, A.M. \& Saldana, J. (2014). Qualitative aata analysis: a methods sourcebook (3th ed). California: SAGE Publications, Inc.

Peter, E.E. (2012). Critical Thinking: Essence for teaching mathematics and mathematics problem solving skills. African Journal of Mathematics and Computer Science Research, 5, 39-43. Retrieved from: http://www.academicjournals.org/AJMCS $\mathrm{R}$.

Purnomo, H., \& Wilujeng, I. (2016). Pengembangan bahan ajar dan instrumen penilaian IPA tema indahnya negeriku penyempurnaan buku guru dan siswa Kurikulum 2013. Jurnal Prima Edukasia, 4(1), $\quad 67 \quad$ - 78. doi:http://dx.doi.org/10.21831/jpe.v4i1.76 $\underline{97}$

Republik Indonesia. (2003). Undang-undang RI Nomor 20, Tahun 2003, tentang Sistem Pendidikan Nasional.

Roberts, T. G., \& Dyer, J. E. (2005). The relationship of self-efficacy, motivation, and critical thinking disposition to achievement and attitudes when an illustrated web lecture is used in an online learning environment. Journal of agricultural education, 46(2), 12-23.

Santrock, J.W. (2007). A topical approach to lifespan development $\left(3^{\text {rd }}\right.$ ed.). New York: McGraw-Hill Companies, Inc.

Schunk, D. H., Pintrich, P. R., \& Meece, J. L. (2015). Motivation in education: Theory, research, and applications. Upper Sadle River: Pearson Education, Inc.

Snyder, L. G., \& Snyder, M. J. (2008). Teaching critical thinking and problem solving skills. The Journal of Research in Business Education, 50(2), 90.

Tella, A. (2007). The impact of motivation on student's academic achievement and learning outcomes in mathematics among secondary school students in Nigeria. Eurasia Journal of Mathematics, Science \& Technology Education, 3(2), 149-156.

Thompson, C. (2011). Critical thinking across the curriculum: Process over output. International Journal of Humanities and Social Science, 1(9), 1-7.

Tilaar, H.A.R. (2004). Paradigma baru pendidikan nasional. Jakarta: Rineka Cipta. 